\title{
SUPPORT OF SCIENCE FOR POLITICAL DECISIONS ABOUT PHYSICAL EDUCATION IN SLOVENIA
}

\author{
Gregor Jurak $^{1}$, Marjeta Kovač ${ }^{1}$, Gregor Starc' ${ }^{1}$, and Janko Strel ${ }^{1}$
}

${ }^{1}$ Faculty of Sport, University of Ljubljana, Slovenia

\section{SUMMARY}

The changes in Physical Education (PE) curriculum, amount of PE lessons, number of students in class, improvement in class environment, amount and competency of PE teachers and increase of extra-curricular and out-of school sport programmes have effects on physical fitness of young people. It is very important to have special concern about this factors/systematic measures in public schools to ensure more equal opportunities for each child.

Key Words: physical fitness, Slovenia, young people.

\section{INTRODUCTION}

The lives of young people in developed countries today are mostly characterised by the modern information era. Many young people live in a half-virtual world of web social networks; they also choose to participate in physical activities less often than they used to (Froberg \& Andersen, 2010; Strel, Kovač, \& Jurak, 2007; Strong et al., 2005). In connection with the sheltering praxis of parents (restriction of children from access to public spaces, e.g. playing on city playgrounds, from walking alone in their own neighbourhood, from crossing the street by themselves), individualisation (children's incorrect impressions of their role in society) and permissive education, sedentary lifestyles are common among young people (Armstrong, 2007; De la Cruz-Sanchez \& PinoOrtega, 2010; Ferreira et al., 2007; Jurak, 2006; Strel et al., 2007). According to the findings of secular trend studies, it can be concluded that changes in the lifestyles of young people in developed countries are manifesting themselves in an increased subcutaneous fatness (Olds, Ridley, \& Tomkinson, 2007; Strel et al., 2007), a higher proportion of the overweight population (Currie et al., 2004; Lobstein \& Frelut, 2003; Malina, 2007; Strel et al., 2007; Wedderkopp, Froberg, Hansen, \& Andersen, 2004), and deterioration of their cardiorespiratory and motor fitness (Froberg \&
Andersen, 2010; Strel et al., 2007; Tomkinson \& Olds, 2007; Tomkinson, Olds, \& Borms, 2007).

The main part of children's physical activity is presently allocated to regular PE classes in schools (Bailey, 2006). Sufficient quantity of a quality PE programs can contribute significantly to the overall amount of moderate-to-intense physical activity of the school-age child (Trudeau \& Shephard, 2005). PE should also serve as a venue to prepare students to be physically educated person: to teach them the importance of regular physical activity for health and to build skills that support active lifestyles (Ding, Sallis, Kerr, Lee, \& Rosenberg, 2011; Fairclough \& Stratton, 2005; Froberg \& Andersen, 2010; Sallis, Prochaska, \& Taylor, 2000). In addition, the fact that motor development and physical fitness are closely related to cognitive and emotional-social areas of a child's development (Kovač \& Strel, 2000; Sibley \& Etnier, 2003; Tomporowski, 2003) should not be disregarded. PE is therefore very important systematic tool for physical development of young people.

The decision-making process concerned with key issues of the education profession is not always kept within the domain of the critical professional and/ or scientific public. It is usually controlled by the governing political party, which legitimately has been granted the right to make decisions, albeit that these decisions can seriously hinder the development of an 
educational system if exercised solely on the ruling party's authority without due regard to any carefully considered research-based arguments. Populist decisions on, and in, an educational system are especially questionable professionally.

From this point of view, it is not just important that scientist and experts notice and understand the changes and needs of young people. They should also listen to the problems facing teachers, coaches and parents and should be involved in the process of looking for solutions which derive from actual situations and can be realistically carried out. Especially important are systemic measures in the area of PE which have long-term positive or negative consequences. Within this paradigm some cases of application of research findings to PE practice in Slovenia will be presented.

\section{METHODS}

This paper particularly draws from several databases, carried out by University of Ljubljana. The representative data of physical fitness and lifestyle's patterns of young people and environmental impacts on their physical activities have been collected on sample around 3.500 students aged 7 to 19 in Slovenia since 1970 within BPS SLO study (Bio-psychosocial characteristics of Slovenian children and youth) pro (Strel et al., 2007). Some morphological characteristics and motor fitness of the whole population of children and youth aged 7 to 18 have been systematically monitored since 1987 as part of the SLOFIT (see Table 1; Strel, 1997). To get broader picture about factors influencing on physical fitness of young people data from some other research studies will be presented:

\section{TABLE 1}

Tests in SLOFIT system.
- Sports and physical activities levels of Slovenian children and youth (Jurak, Kovač, \& Strel, 2002a, 2002b; Jurak et al., 2003; Strel et al., 2007; Jurak et al., 2014; Sorić et al., 2014),

- Excusing from PE lessons (Jurak \& Kovač, 2011a, 2011b),

- Sports talented youth in Slovenian educational system (Jurak et al., 2005),

- Lifestyles of Slovenian high school students (Jurak, 2006),

- Environmental factors of physical activity of primary school students (Starc et al., 2011),

- Competency of PE teachers (Kovač, Sloan, \& Starc, 2008),

- Comparison of physical fitness of Slovenian and Serbian young people (Jurak et al., 2011a),

- The analysis of school sports area with guidelines for further investments (Jurak et al., 2011b).

Motor fitness of children in SLOFIT is assessed by $t$ and $M_{t}$ values. $T$ values are normalized values of tests results in certain variable by ranking quantile normalization using whole population of the same gender and age as a reference group. $M_{t}$ values is computed by averaging the normalized ( $t$-values) scores of all eight motor tests and linearly transformed, so that the $M_{t}$ score in entire population (at particular gender and age) has normal distribution with mean of 50 and standard deviation of 10.

Following, three major problems in physical fitness of Slovenian young people are presented. For each research finding measures and key actions for PE practice on policy (PE curriculum, national programme of sport, guidelines for PA in Slovenia, standards for PE) and teacher's level will be introduced. This paper will therefore elucidate that there is a large potential

\begin{tabular}{llll}
\hline Abbreviation & \multicolumn{1}{c}{ Variable } & \multicolumn{1}{c}{ Measured capacity } & Measuring unit \\
\hline ATT & Body height & Longitudinal dimension of the body & $\mathrm{mm}$ \\
\hline ATV & Body weight & Voluminosity of the body & $\mathrm{kg}$ \\
\hline AKG & Triceps skinfold & Subcutaneous fatness & $\mathrm{mm}$ \\
\hline DPR & Arm plate tapping & Speed of alternate motion & no. of repetitions \\
\hline SDM & Standing long jump & Explosive power & $\mathrm{cm}$ \\
\hline PON & Polygon backwards & Co-ordination of whole body movements & $\mathrm{s}$ \\
\hline DT & Sit-ups & Strength of abdominal muscles & no. of repetitions \\
\hline PRE & Bend forward on a bench & Flexibility & $\mathrm{cm}$ \\
\hline VZG & Bent arm hang & Muscular endurance of the shoulder girdle and arms & $\mathrm{s}$ \\
\hline T60 & 60-metre run & Sprint speed & $\mathrm{s}$ \\
\hline T600 & 600-metre run & General endurance & $\mathrm{s}$ \\
\hline
\end{tabular}


for changes of physical fitness of young people in scientists' engagement on application of research findings to PE practice, especially on political level.

\section{DECREASING OF PHYSICAL FITNESS OF YOUNG PEOPLE IN SLOVENIA}

Increased body weight and fatness are markedly presence at Slovenian children and youth. In 19-yearsold youth $2.2 \%$ of boys and $1.8 \%$ of girls could be class among obese, on the other side number of underweight girls is increasing because of feeding disturbance - there share is between 5 and 10\% (Starc, Strel, \& Kovač, 2010). Tracking overweight and obesity from childhood to young adulthood (Starc \& Strel, 2011) shows that height, weight and BMI at 18 years were well predicted from childhood and become more predictable with age, while TSF was not. Obese and overweight children had the greatest risk of becoming obese or overweight young adults. The history of their weight shows that $40.0 \%$ of males and $48.6 \%$ of females who were obese at 18 years had already been obese at 7 years.

\section{FIGURE 1}

Negative changes in motor potential of Slovenian youth in period 1990-2008.

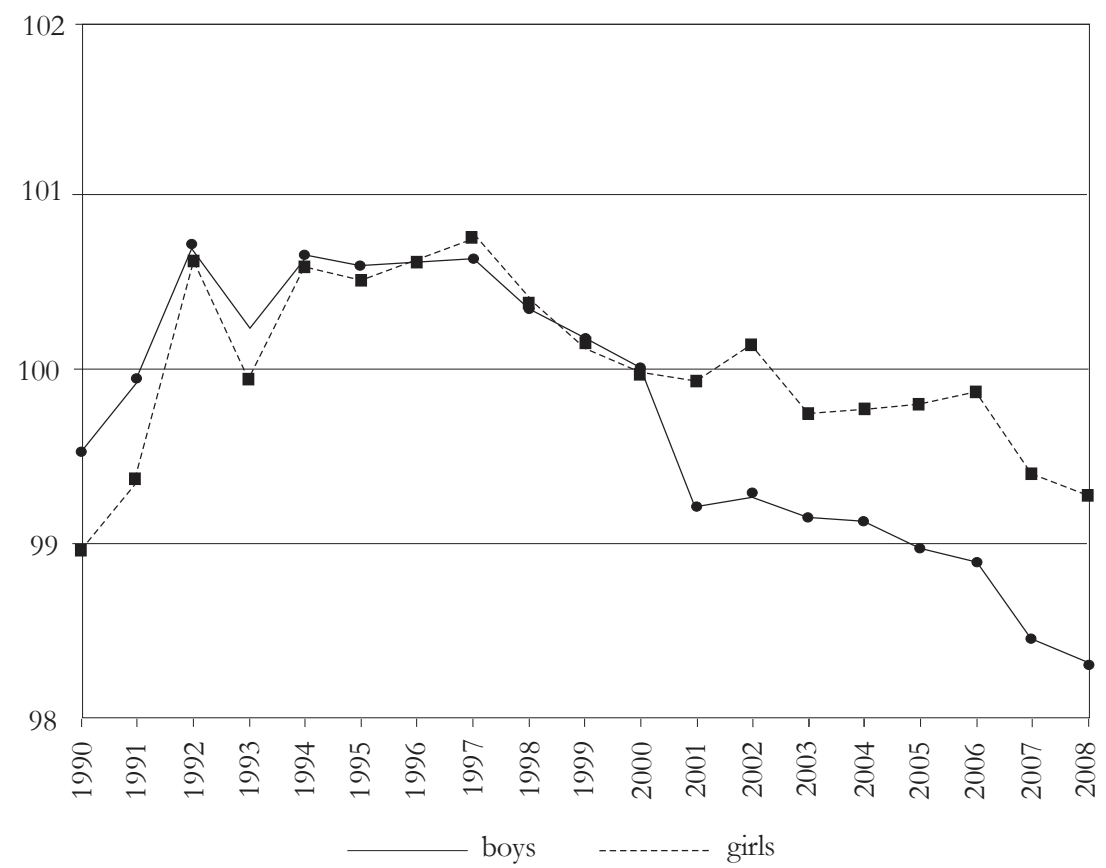

Similar negative changes are also noticed in motor fitness of Slovenian young people: deterioration of their motor potential, mainly endurance and strength (Starc \& Strel, 2011; Strel et al., 2007). The findings also demonstrate a decline of results in activities which require young people's body movement (Strel et al., 2007). On the other side, sporting activity of Slovenian primary school children is increasing (Jurak et al., 2003; Strel et al., 2007); primary school children are physically active 1 hour per day (Strel et al., 2007). On this basis it can be concluded, that recommended and actual physical activity (60 minutes of moderate to vigorous physical activity per day) is not enough to neutralise all negative effects of nowadays lifestyles of Slovenian youth!

\section{Applications}

90 min of moderate to vigorous physical activity per day should be recommended for children aged 6 to $19.50 \%$ of this physical activity should be allocated in school in regular PE lessons and other curriculum activities. In such manner few changes of Slovenian PE curriculum were done:

- Emphasis on endurance sports activities. The effects of modern routines, the informational way of life and democratic education are reflected in the ever decreasing endurance of children and youth. It is suggested that PE teachers concentrate on organised exercise and encourage children to become involved in endurance activities. Various contents of curriculum are available to achieve this aim (not just running) and they should be practised outside more often than currently, even in slightly adverse weather conditions. Heart rate monitors could be successfully used during exercise.

- "Play is fun, but it's hard work too!"Pleasure effects should be outcome of systematic, goal oriented 
planned and professionally lead PE lessons. Some modern trends of society, like individualisation, permissive education principles, taking care about pleasure, are in contradiction with a lot of principles of PE. PE in not only pleasure if we are planning to meet goals, it is also pain. It is not only relaxation, first it is effort...

- Education for understanding sport. Only young people who understand the importance of $\mathrm{PE}$ can in their free time and subsequent adult life be expected to undertake physical activity suited to their abilities, wishes and needs. The teaching of PE should include theoretical contents, which teachers should present alongside practical work. Teachers should use various didactic materials (posters, study notes, computer programmes, computer games etc.) in order to pass on the theoretical contents of sport.

Despite some attempts to shortening the standards of PE teaching we were manage to keep them. This was done on the basis of research findings arguments. Basic standards of PE teaching in Slovenia are:

- an average no. of students per teacher is 16.6 students at age of 6 to 11 and 8.2 students at the age of 12 to 14 (Statistični urad Republike Slovenije, 2011),

- competencies of PE teachers are relatively high (Kovač et al., 2008),

- material conditions for PE are good, since every primary school have at least one sports hall, most of them also have outdoor sports terrains (Jurak et al., 2011b).

In Slovenia we have national programme of sport (Jurak et al., 2010) which define public interest and consequently public finances in sport out of school system. One of strengths of this programme is intertwining with school programme in some project:

- Interventional kinesiological programmes (classes with additional PE, project Healthy lifestyle) ${ }^{2}$.

- Hurrah, free time (spending summer holidays in school sports halls; cooperation with NGO). Project started on the basis of our findings (Jurak et al., 2003) that students would like to take part in sports activities in the school sports halls during the summer holidays. Only about $10 \%$ of programmes organized during the summer holidays took place in school sports halls in that time; in such way sports activities could be organized with minimal financial costs.

- National media campaign about the significance of youth sport.
- Improved quality of diet at home and at school (planned diet at school).

- "A minute for health" and "Recreational break".

- "Safe paths" to allow safe walking or cycling to and from school.

- Public (fee-free) sports facilities.

- National and local communities sports schools (co-financing of university educated professionals for working with young sports people).

\section{PHYSICAL AND MOTOR DEVELOPMENT OF YOUNGER SCHOOL CHILDREN}

The most favourable period for the development of a child's various motor abilities is between the ages of 6 and 12 (Gallahue \& Ozmun, 1998); developmental aspects ignored during this period are difficult or impossible to compensate for later. Practitioners and researchers have been warning for a long time that children in this age period require at least an hour of quality physical exercise every day, provided by professionally competent teachers. Studies (Starc et al., 2010; Strel et al., 2007) of the physical development of children aged 6-10 have revealed that the proportion of overweight and obese children in Slovenia has been increasing particularly in this age group (see Figure 2) and that the physical fitness of these children is decreasing, more so than amongst adolescent youth.

In the first six years of schooling, Slovenian children have three PE lessons (45 minutes each) per week and that legislation prescribes that all the subjects in the first three-year period are taught by elementary class teachers. In the fourth and fifth years, two or three subjects can be taught by a subject specialist (including PE). Notably, current legislation does not allow PE teachers to teach PE independently in the first three years of primary school but rather they have to be accompanied by elementary school class teachers. Such joint teaching comes at a cost because schools are responsible for the necessary financial resources either through local municipalities, or parents or their own sources (Jurak et al., 2005).

Some primary schools understand the importance of everyday physical activity on children's physical fitness and have been offering an enhanced PE curriculum, containing daily PE lessons and joint teaching of elementary class and PE teachers in the first four years of schooling since 1984 (Jurak et al., 2005). In longitudinal study Jurak et al. (2011c, 2013) examined the effects of the implementation of such school-based kinesiological intervention. The kine- 
FIGURE 2

Comparison of overweight and obese pupils in Slovenia by age (1991-2009).

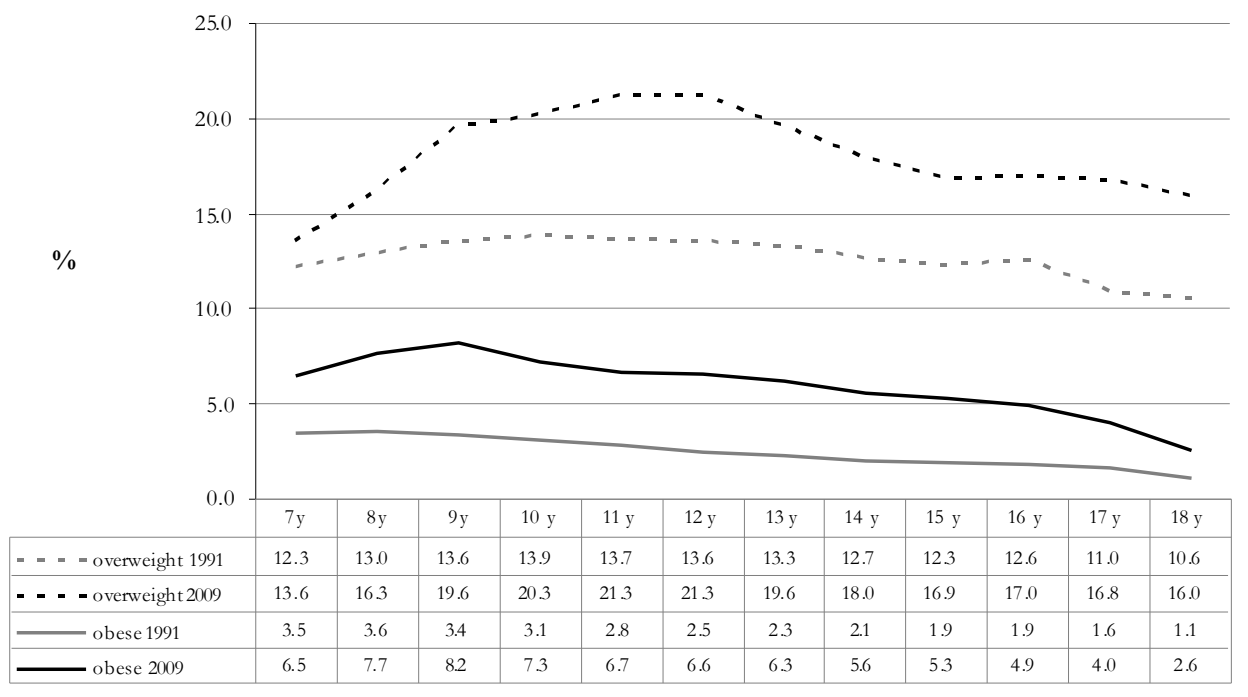

siological intervention group achieved better results than the control group in all motor variables, especially in the motor tasks of polygon backwards, sit-ups for 30 seconds, and 600-metre run. This is particularly important because the muscular endurance and running speed of children of that age have been falling in recent decades. The results point to a better quality of sessions in kinesiological intervention consisting of a wide range of motor skills, a suitable organisation of work and greater amounts of exercise.

\section{Applications}

Further development of interventional sports programme depends on the initiative of parents for organising them in individual schools as well as on financial support of local community and the government, on prospective financial contribution of parents for above-standard services and on the reasonable flexibility of a model, which would permit various organisational solutions according to the characteristics of school environment. The systemic co-financing of such joint teaching through action plan of national programme of sport has been providing.

On the research findings and good experience with interventional sports programme two years ago national project Healthy lifestyle also started, funded from European funds. In this project students in primary school have 2 extra hours of optional physical activities per week. These activities are free of charge, led by PE teachers. PE teachers are extra employed teachers for half time employment. This project represents starting point for many young PE teachers, who proved themselves and get permanent full time job.

\section{PHYSICAL ACTIVITY OF SECONDARY SCHOOL STUDENTS}

During the period of adolescence, when young people are at a crossroads of searching for their future path and the formation of their own identity, their motivation for participation in various activities changes. Public opinion research shows, particularly for younger age groups, that major values, once based on strong ideologies, are being replaced by values closer to the individual and personal experience. Their different interests, the supply of comfort via the click of the mouse and a virtual world without realistic problems lead young people into more passive spending of their free time (Brettschneider \& Naul, 2004; Jurak, 2006; Jurak et al., 2003; Riddoch et al., 2004), most often in front of TV screens and play stations and on mobile telephones etc. "Screenagers" feel comfortable only in virtual world in which they communicate only with the computer screen (Rushkoff, 2006), which prevents them from acquiring important social competencies - expressed by the term cocooning. Specific ways of spending free time at weekends for some young people usually include risky types of behaviour, such as smoking, drug use and drinking alcohol (Jurak, 2006).

For modern youth, physical activity has lost its primary value - enjoyment in movement. Activity, particularly sport, does not represent any challenge for adolescent young people today, because results require time and effort, as the effects of motor learning and achieving adequate fitness are possible only with a sufficient number of repetitions of specific motor patterns. Jurak et al. (2003) found that teenag- 
ers feel cramped by being included in the organised types of sport activity offered by schools and sport clubs. This represents "traditionalism" and "ideology", whereas they wish to practise in their own time. Certain sports that young people participate in mostly in an informal way have become a part of the culture of teenage behaviour and dressing (skateboarding, snowboarding, mountain biking etc.).

It is acknowledged that physical fitness of youth has a correlation with the amount of free time they devote to sporting activities (Jurak et al., 2003). In recent years, some major changes in the way Slovenian young people spend their free time have been observed. Boys are more physically active in their free time than girls; nevertheless, the amount of free-time physical activity gradually decreases with age in both genders (Jurak et al., 2003; Kovač, Jurak, Starc, \& Strel, 2007). The proportion of secondary-school boys who do not participate in any sport activity during summer holidays rose from $10.6 \%$ in 1993 to $15.2 \%$ in 2004 (Strel et al., 2007).

As a result, studying the lifestyles of young people has also become the subject of numerous research projects in Slovenia, indeed in many other countries

FIGURE 3

Differences (interaction plots) among secondary school students in different educational programmes.
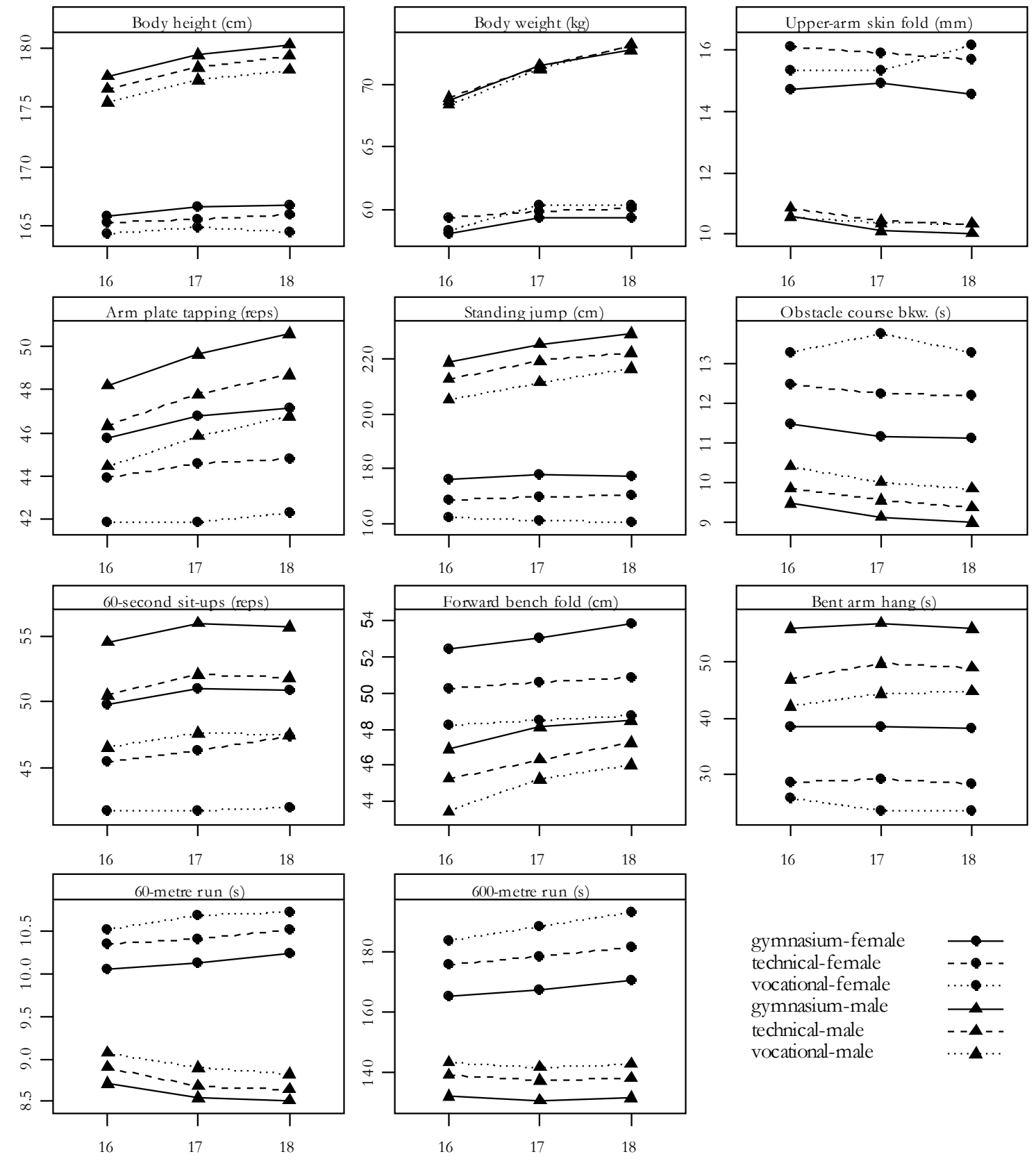

age (yrs) 
across the globe. Jurak (2006) found that in Slovenia young people can be divided in two extreme typical groups according to their lifestyle, which have, in relation to the (un)healthy habits, been named the "coffee and cigarettes" and the "sport" lifestyles. The groups show statistically significant differences not only in free time sporting activity, regular smoking and alcohol drinking, academic results, educational level of their parents, but also in eating meals and self-evaluation of well-being. Two extremes of lifestyles is also visible in their motor performance, since proportion of students with worse physical performance index $\left(M_{t}<40\right)$ increase in secondary schools.

Next problem is amount of PE in secondary schools. It is a paradox that students in secondary school education who follow different academic programmes have different amounts of PE lessons, as the need for physical activity is the same for all groups. Consequently, it would be legitimate reasonable to expect that in the subject intended to foster a healthy lifestyle, everyone be offered optimal developmental opportunities. Furthermore, in view of differences between young people, those in need of more motor encouragement should also have more PE lessons.

We analysed differences in various characteristics between groups of students from different secondary school programs according to their gender, age and the type of programmes they attend (Leskošek, Kovač, $\&$ Strel, 2007). Amongst others, the findings featured in Figure 3 revealed:

- the type of programme differentiates boys and girls the most with the best results in all tests achieved by boys and girls in gymnasia school programmes, followed by technical schools programmes and the worst results achieved by boys and girls from vocational schools programmes;

- the differences are smaller amongst boys than girls;

- the greatest difference between the types of programme - whilst controlling for age and gender - was observed in the results of sit-ups and arm-plate tapping tests; and

- statistically significant differences were also observed in morphological differences, particularly in body height and the amount of body fat.

The researchers concluded that these differences may occur as a result of the students' different socioeconomic environments. The less favourable morphological structure of students from vocational programmes is probably a result of their lower amount of physical activity and unsuitable eating habits. The results confirm the findings of other researchers suggesting that vocational schools' students have the worst nutritional habits (Gabrijelčič Blenkuš, 2001). The poorer physical fitness of vocational schools' students is probably a result of the more infrequent free-time sport participation, the lower amount of school PE lessons as well as attitudes to sport activity, which serve as an indicator of a quality way of spending one's free time (Jurak et al., 2003). There is also a problem of excusing from PE practise, where girls from secondary school dominate (Jurak \& Kovač, 2011a, 2011b).

\section{Applications}

A systematic, structured PE process has important effects on the physical fitness of young people and their knowledge about healthy lifestyles. At the same time, it can serve as an important compensational tool. The appropriate physical activity can effectively prevent the negative effects of work stress, which are in the case of vocational load usually one-sided (most often also asymmetrical), often static and can in the long-term cause physical defects. Hence, modernisation of contents in secondary school PE curriculums has been made. There are more health related contents, education for understanding sport and emphasis on endurance sports activities and neutralisation of occupational health problems.

To decrease the excusing from PE practise guidelines adopted by national association of PE teachers has been set in two directions (Jurak \& Kovač, 2011a, 2011b):

- Limitation of reasons for excusing (more individualization during lessons, appropriate examination and evaluation, improvement of class environment, establishing school fond of sport outfit, improve equipment, preserve the numeric normative of pupils, appropriate schedule of PE lessons).

- Implementation of universal school rules for excusing and activities of the excused students according to curriculum: including the excused students as assistants, learning theoretical materials of PE, preparation of didactic materials.

As schools cannot provide the recommended amount of daily physical activity for all youth within the compulsory curriculum, suitable programmes must be set and the amount of public finance for extra-curricular and out-of school sport programmes needs to be increased. These programmes should be well organized with ensured free access to them and so help in increasing the amount of young people's 
daily physical activity regardless of social status. Jurak et al. (2002b) found that young people do not have any constrains to join sports activities during summer holidays if organised by schools, only that it is organised in a manner acceptable for them. On such basis the project of installing lights for open sport areas (part of project Hurrah, free time) has been founded. Within project youth could, with the assistance of mentors, organise their own sport activities by themselves at evenings: a) activities at evenings when they want to hang up together, b) participation in sport activities, which belong to their life style, c) free of charge activities (Jurak et al., 2002b).

\section{REFERENCES}

Armstrong, N. (2007). Physical fitness and physical activity patterns of European youth. In W. D. Brettschneider \& R. Naul (Eds.), Obesity in Europe: young people's physical activity and sedentary lifestyles (pp. 27-56). Frankfurt am Main, Germany: Peter Lang.

Bailey, R. (2006). Physical education and sport in schools: a review of benefits and outcomes. $J$ Sch Health, 76(8), 397-401. doi: 10.1111/j.1746-1561.2006.00132.x

Brettschneider, W., \& Naul, R. (2004). Study on young people's lifestyle and sedentariness and the role of sport in the context of education and as a means of restoring the balance. Final report. Paderborn, Germany: EC, Directorate-General for Education and Culture, Unit Sport.

Currie, C., Roberts, C., Morgan, A., Smith, R., Settertobulte, W., Samdal, O., \& BarnekowRasmussen, V. (2004). Young people's health in context. Health behaviour in school-aged children (HBSC) study: international report from the 2001/2002 survey. Copenhagen, Denmark: World Health Organization Regional Office for Europe.

De la Cruz-Sanchez, E., \& Pino-Ortega, J. (2010). An active lifestyle explains sex differences in physical performance in children before puberty. Coll Antropol, 34(2), 487-491.

Ding, D., Sallis, J. F., Kerr, J., Lee, S., \& Rosenberg, D. E. (2011). Neighborhood environment and physical activity among youth a review. $A m \mathrm{~J}$ Prev Med, 41(4), 442-455. doi: 10.1016/j. amepre.2011.06.036

Fairclough, S., \& Stratton, G. (2005). 'Physical education makes you fit and healthy'. Physical education's contribution to young people's physical activity levels. Health Educ Res, 20(1), 14-23. doi: 10.1093/her/cyg101
Ferreira, I., van der Horst, K., Wendel-Vos, W., Kremers, S., van Lenthe, F. J., \& Brug, J. (2007). Environmental correlates of physical activity in youth - a review and update. Obes Rev, 8(2), 129154. doi: 10.1111/j.1467-789X.2006.00264.x

Froberg, K., \& Andersen, L. B. (2010). The importance of physical activity for childhood health. M. Kovač and G. Jurak (Eds.), Proceedings of the Fifth International Congress Youth Sport 2010 (pp. 41-46). Retrieved from http://www. youthsport2010.si/images/stories/SM2010/ proceedings1.pdf

Gabrijelčič Blenkuš, M. (2001). Some nutritional habits of secondary-school students in Ljubljana with an emphasis on differences between genders. Slovenian Journal of Public Health, 40(Suppl), 135-143.

Gallahue, D. L., \& Ozmun, J. (1998). Understanding motor development: Infants, children, adolescents, adults. Boston, MA: McGraw-Hill.

Jurak, G. (2006). Sports vs. the "cigarettes \& coffee" lifestyle of Slovenian high school students. Anthropological Notebooks, 12(2), 79-95.

Jurak, G., Cooper, A., Leskošek, B., Kovač, M. (2013). Long-term effects of 4-year longitudinal school-based physical activity intervention on the physical fitness of children and youth during 7-year follow-up assessment. Central european journal of public health, 21(4), 190-195.

Jurak, G., Kolar, E., Kovač, M., Bednarik, J., Štrumbelj, B., \& Kolenc, M. (2010). Proposal of National programme of sport in Republic of Slovenia 2011-2020. Sport, 58(1-2), 133-172.

Jurak, G., \& Kovač, M. (2011a). Frequency and characteristics of excuses given by students attending special sports classes of secondary school to avoid participating in physical education class. Slovenian Journal of Public Health, 50(2), 95-105. doi: 10.2478/v10152-010-0032-7

Jurak, G., \& Kovač, M. (2011b). Opravičevanje med poukom športne vzgoje $\mathrm{v}$ osnovni šoli [Adopting the teaching of physical education in elementary school]. Didactica Slovenica, 26(4), 1831.

Jurak, G., Kovač, M., \& Strel, J. (2002a). How Slovene primary school pupils spend their summer holidays. Kinesiologia Slovenica, 8(2), 3543.

Jurak, G., Kovač, M., \& Strel, J. (2002b). Spending of summer holidays of Slovenian secondary school children. Acta Universitatis Carolinae Kinanthropologica, 38(1), 51-66.

Jurak, G., Kovač, M., \& Strel, J. (2011c). Influence of the Enhanced Physical Education 
Curriculum on the Physical Fitness of Children. Croatian Journal of Education, 13(4), 41-59, 6070.

Jurak, G., Kovač, M., Strel, J., Starc, G., Majerič, M., Filipčič, T., \& Bednarik, J. (2003). Sports activities of Slovenian children and young people during their summer holidays. Ljubljana, Slovenia: University of Ljubljana, Faculty of Sport.

Jurak, G., Kovač, M., Strel, J., Starc, G., Žagar, D., \& Cecić Erpič, S. (2005). Śportno nadarjeni otroci in mladina $v$ slovenskem solskem sistemu [Sports talented children and youth in Slovenian educational system]. Koper, Slovenia: Annales, Univerza na Primorskem, Znanstvenoraziskovalno središče Koper.

Jurak, G., Radisavljević Janić, S., Milanović, I., Strel, J., Leskošek, B., \& Kovač, M. (2011). The comparison of physical fitness of 13-year-old students from Ljubljana and Belgrade. I. Prsaklo and D. Novak (Eds.), Proceedings of International Congress "Tjelesna $i$ zdravstvena kultura u 21. stoljecu - kompetencije ǔ́enika". Zagreb, Croatia: Hrvatski kineziološki savez

Jurak, G., Sorić, M., Starc, G., Kovač, M., MišigojDuraković, M., ... Strel, J. (2014). School day and weekend patterns of physical activity in urban 11-year-olds: A cross-cultural comparison. American Journal of Human Biology, 9/2014 (in print).

Jurak, G., Strel, J., Kovač, M., Bednarik, J., Filipčič, T., Leskošek, B., ... Majerič, M. (2011). Analyses of school sport infrastructure. Partial report. Ljubljana, Slovenia: University of Ljubljana, Faculty of Sport.

Kovač, M., Jurak, G., Starc, G., \& Strel, J. (2007). Šport in življenjski slogi slovenskih otrok in mladine. [Sport and lifestyles of Slovenian children and youth] Ljubljana, Slovenia: University of Ljubljana, Faculty of Sport.

Kovač, M., Sloan, S., \& Starc, G. (2008). Competencies in physical education teaching: Slovenian teachers' view and future perspectives. European Physical Education Review, 14(3), 299323. doi: $10.1177 / 1356336 \mathrm{X} 08095668$

Kovač, M., \& Strel, J. (2000). The relations between intelligence and manifest motor space. Kinesiology, 32(1), 15-25.

Leskošek, B., Kovač, M., \& Strel, J. (2007). A comparison of the physical characteristics and motor abilities of boys and girls attending different high-school programmes. Acta Universitatis Carolinae Kinanthropologica, 42(2), 85101.
Lobstein, T., \& Frelut, M. L. (2003). Prevalence of overweight among children in Europe. Obes Rev, 4(4), 195-200. doi: 10.1046/j.1467-789X.2003.00116.x

Malina, R. M. (2007). Physical fitness of children and adolescents in the United States: status and secular change. Med Sport Sci, 50, 67-90. doi: 10.1159/000101076

Olds, T. S., Ridley, K., \& Tomkinson, G. R. (2007). Declines in aerobic fitness: are they only due to increasing fatness? Med Sport Sci, 50, 226-240.

Riddoch, C. J, Bo Andersen, L., Wedderkopp, N., Harro, M., Klasson-Heggebo, L., Sardinha, L. B, ... Ekelund, U. (2004). Physical activity levels and patterns of 9- and 15-yr-old European children. Med Sci Sports Exerc, 36(1), 86-92. doi: 10.1249/01.MSS.0000106174.43932.92

Rushkoff, D. (2006). Screenagers. Cresskill, NJ: Hampton Press.

Sallis, J. F., Prochaska, J. J., \& Taylor, W. C. (2000). A review of correlates of physical activity of children and adolescents. Med Sci Sports Exerc, 32(5), 963-975. doi: 10.1097/00005768200005000-00014

Sibley, B. A., \& Etnier, J. L. (2003). The relationship between physical activity and cognition in children: A meta-analysis. Pediatric Exercise Science, 15(3), 243-256.

Sorić, M., Starc, G., Borer, K., Jurak, G., Kovač, M., Strel, J., \& Mišigoj-Duraković, M. (2014).

Associations of objectively assessed sleep and physical activity in 11-year old children. Annals of human biology, 41(3), 1-7. doi: 10.3109/03014460.2014.928367

Starc, G., Kovač, M., Jurak, G., Dremelj, S., Kovač, P., \& Mišigoj Duraković, M. (2011). Daily energy intake, physical activity and physical fitness levels and some eating habits of 11-yearold students. In D. Milanović and G. Sporiš (Eds.), Proceedings of 6th International Scientific Conference on Kinesiology (pp. 131). Zagreb, Croatia: Faculty of Kinesiology, University of Zagreb.

Starc, G., \& Strel, J. (2011). Tracking excess weight and obesity from childhood to young adulthood: a 12-year prospective cohort study in Slovenia. Public Health Nutr, 14(1), 49-55. doi: 10.1017/ S1368980010000741

Starc, G., Strel, J., \& Kovač, M. (2010). Telesni in gibalni razvoj slovenskih otrok in mladine v stevilkah. Ślsko leto 2009/10. [Physical and motor development of Slovenian children and youth in figures. 2009/10 academic year] Ljubljana, 
Slovenia: University of Ljubljana, Faculty of Sport.

Strel, J. (1997). Sports Educational Chart. Ljubljana, Slovenia: Ministry of Education and Sport.

Strel, J., Kovač, M., \& Jurak, G. (2007). Physical and motor development, sport activities and lifestyles of Slovenian children and youth changes in the last few decades In W. D. Brettschneider and R. Naul (Eds.), Obesity in Europe: young people's physical activity and sedentary lifestyles (pp. 243-264). Frankfurt am Main, Germany: Peter Lang.

Strong, W. B., Malina, R. M., Blimkie, C. J., Daniels, S. R., Dishman, R. K., Gutin, B., ... Trudeau, F. (2005). Evidence based physical activity for school-age youth. J Pediatr, 146(6), 732-737. doi: 10.1016/j.jpeds.2005.01.055

Statistični Urad Republike Slovenie [SURS]. (2011). Primary school education in Slovenia at the end of academic year 2009/10 and in the beginning of 2010/11 academic year. Ljubljana, Slovenia: SURS.

Tomkinson, G. R., \& Olds, T. S. (2007). Secular changes in pediatric aerobic fitness test performance: the global picture. Med Sport Sci, 50, 46-66. doi: 10.1159/000101075

Tomkinson, G. R., Olds, T. S., \& Borms, J. (2007). Who are the Eurofittest? Med Sport Sci, 50, 104 128. doi: 10.1159/isbn.978-3-318-01396-2; doi: $10.1159 / 000101355$

Tomporowski, P. D. (2003). Cognitive and behavioural responses to acute exercise in youths: A review. Pediatric Exercise Science, 15(3), 348-359.

Trudeau, F., \& Shephard, R. J. (2005). Contribution of school programmes to physical activity levels and attitudes in children and adults. Sports Med, 35(2), 89-105. doi: 10.2165/00007256200535020-00001

Wedderkopp, N., Froberg, K., Hansen, H. S., \& Andersen, L. B. (2004). Secular trends in physical fitness and obesity in Danish 9-year-old girls and boys: Odense School Child Study and Danish substudy of the European Youth Heart Study. Scand J Med Sci Sports, 14(3), 150-155. doi: 10.1111/j.1600-0838.2004.00365.x

Received: November 8, 2013

Revision received: November 7, 2014

Accepted: November 7, 2014

Correspondence to:

Gregor Jurak, PhD Faculty of Sport

Gortanova 22

10000 Ljubljana

Slovenia

Phone: 0038615207783

E-mail: gregor.jurak@fsp.uni-lj.si 